\title{
Postoperative bisphosphonate do not significantly alter the fusion rate after lumbar spinal fusion: a meta-analysis
}

\author{
Jun Mei ${ }^{1,2}$, Xiaoxu Song ${ }^{2}$, Xiaoming Guan², Dou Wu ${ }^{2}$, Junjie Wang ${ }^{3}$ and Qiang Liu ${ }^{2^{*}}$ (D
}

\begin{abstract}
Background: To evaluate the effect of postoperative BP treatment on improving the fusion rate after lumbar spinal fusion surgery by performing a meta-analysis of randomized controlled trials (RCTs) and other comparative cohort studies.

Methods: A comprehensive search of PubMed, EMBASE, the Web of Science, and the Cochrane Central Register of Controlled Trials was performed for RCTs and other comparative cohort studies on the effect of BP treatment on improving the fusion rate after lumbar spinal fusion surgery. The primary outcome measures were the number of patients with bone formation grades A, B, and C at 12 months of follow-up; fusion rates at 12 and 24 months of follow-up; vertebral compression fracture (VCF) at 12 and 24 months of follow-up; pedicle screw loosening at 24 months of follow-up; and cage subsidence, the Oswestry disability index (ODI), and the visual analogue score (VAS) at 12 months of follow-up. The final search was performed in July 2020.
\end{abstract}

Results: Seven studies with 401 patients were included. Compared with the placebo, BP treatment did not significantly alter the number of patients with bone formation grades A, B, and C, or the VAS at the 12-month follow-up or the fusion rates at the 12- and 24-month follow-ups. In addition, compared with the placebo, BPs significantly reduced the risks of VCF at the 12- and 24-month follow-ups, pedicle screw loosening at the 24-month follow-up, and cage subsidence and the ODI at the 12-month follow-up.

Conclusions: Postoperative BPs do not clearly improve bone formation and the fusion rate, but they reduce VCF, cage subsidence, and loosening of pedicle screws after lumbar fusion surgery compared with the control treatment.

Keywords: Bisphosphonates, Spinal fusion surgery, Fusion rate, Osteoporosis, Meta-analysis

\section{Introduction}

Due to the ageing population worldwide, the incidence of numerous diseases associated with ageing has increased; for instance, lumbar degenerative disease is a common condition in humans, and approximately 37\% of the adult population is estimated to suffer from this

\footnotetext{
* Correspondence: sxdyylq001@126.com

${ }^{2}$ Shanxi Bethune Hospital, Shanxi Academy of Medical Science, No. 99, Longcheng Street, Taiyuan 030032, Shanxi Province, China

Full list of author information is available at the end of the article
}

pathological condition [1]. Surgery is usually an inevitable intervention for individuals who do not receive a sufficient benefit from nonsurgical management [2]. Spinal fusion surgery is the most common therapeutic approach for various lumbar degenerative diseases since this treatment relieves pain and resolves neurological symptoms [3, 4]. Successful spinal fusion requires bone formation and remodelling, which requires cooperation between osteoblasts and osteoclasts [5]. According to a classic study, bone formation is graded by CT scans:

C C The Author(s). 2021 Open Access This article is licensed under a Creative Commons Attribution 4.0 International License, which permits use, sharing, adaptation, distribution and reproduction in any medium or format, as long as you give appropriate credit to the original author(s) and the source, provide a link to the Creative Commons licence, and indicate if changes were made. The images or other third party material in this article are included in the article's Creative Commons licence, unless indicated otherwise in a credit line to the material. If material is not included in the article's Creative Commons licence and your intended use is not permitted by statutory regulation or exceeds the permitted use, you will need to obtain permission directly from the copyright holder. To view a copy of this licence, visit http://creativecommons.org/licenses/by/4.0/ The Creative Commons Public Domain Dedication waiver (http://creativecommons.org/publicdomain/zero/1.0/) applies to the data made available in this article, unless otherwise stated in a credit line to the data. 
grade A denotes bridging bone binding to two vertebral bodies nearby, grade $\mathrm{B}$ denotes bridging bone binding to one of vertebral bodies nearby, and grade $\mathrm{C}$ denotes incomplete bridging. The bone formation grade is tightly associated with the fusion rate [6]. Fusion is defined as a bridging bone between the vertebral bodies either inside or outside of the cage. Solid fusion is defined as less than $5^{\circ}$ of angular motion on flexion-extension radiographs at the fusion level combined with the presence of grade $\mathrm{A}$ or B bone formation on coronal multiplanar CT reconstruction scans [6]. However, with ageing, another disease, osteoporosis, also occurs in patients who receive spinal fusion surgery, and studies have suggested that osteoporosis markedly affects the process of bone formation and remodelling $[7,8]$. Despite the development of instrumentation and techniques, nonunion after lumbar spinal fusion surgery remains a primary cause of spinal fusion failure, and managing osteoporosis appears to improve the fusion rate $[9,10]$, as verified by the administration of teriparatide [11].

Bisphosphonates (BPs) are stable pyrophosphate analogues that tightly bind to bone apatites [12]. BPs exert their effect by inhibiting osteoclast differentiation and activity, preventing bone resorption and reducing its turnover; these processes significantly reduce the risk of osteoporosis [13]. BPs are divided into three different generations. The first generation includes clodronate, etidronate, and tiludronate, because they do not contain nitrogen. The second generation includes alendronate and pamidronate, since they have amino-terminal groups. The third generation includes risedronate and zoledronate, as they contain a cyclic side chain [14]. In general, compared with the first generation, the second and third generations exhibit greater affinity for hydroxyapatite in bone and thus have advantages in improving bone metabolism [15]. Currently, most researchers and doctors suggest that BPs should be the first-line medication and advise patients with osteoporosis to receive BP treatment to control their decreased bone mass density (BMD) [16-18]. However, despite the high efficacy of BPs, their effects on managing osteoporosis and subsequently influencing the fusion rate after lumbar spinal fusion surgery remain controversial [19, 20]. Although several animal studies on spinal fusion have reported a positive effect of BPs [21, 22], two recent clinical studies concluded that preoperative BPs had no effect on the nonunion rates [20,23], and one systematic review did not clearly determine whether BP therapy after surgery provided an added benefit after lumbar fusion surgery [24]. A recent meta-analysis has evaluated the effect of postoperative BPs on the fusion rate [25], but the major objective was comparing teriparatide and BPs, and the comparisons in this study were not sufficiently comprehensive.

We therefore evaluated the effect of postoperative BP treatment on improving the fusion rate after lumbar spinal fusion surgery by performing a comprehensive meta-analysis of the published data in randomized

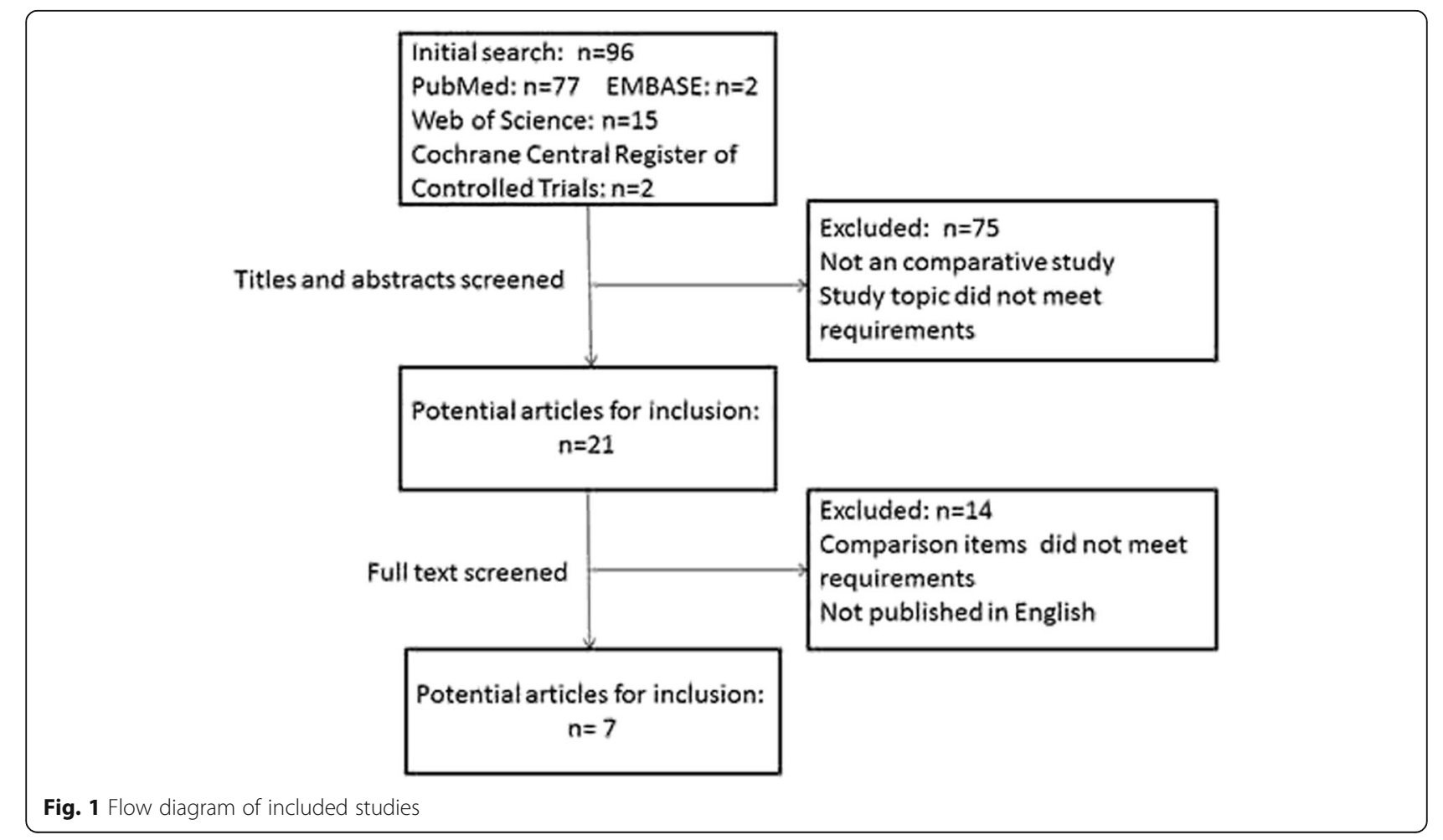


Table 1 Characteristics of the 7 included studies

\begin{tabular}{|c|c|c|c|c|c|c|c|}
\hline First author & Ken Nagahama & Chao Li & Seiji Ohtori & $\begin{array}{l}\text { Sang-Mok } \\
\text { Kim }\end{array}$ & Chao-Wei Tu & Fei Chen & Qirui Ding \\
\hline $\begin{array}{l}\text { Publication } \\
\text { year }\end{array}$ & 2011 & 2012 & 2013 & 2014 & 2014 & 2016 & 2017 \\
\hline $\begin{array}{l}\text { Study } \\
\text { location }\end{array}$ & Japan & China & Japan & South Korea & China & China & China \\
\hline $\begin{array}{l}\text { Surgical } \\
\text { methods }\end{array}$ & Single-level PLIF & $\begin{array}{l}\text { TLIF(with } 23 \text { one } \\
\text { level, } 16 \text { two levels, } 2 \\
\text { three levels in BPs } \\
\text { group, } 21 \text { one level, } \\
19 \text { two levels, } 1 \text { three } \\
\text { levels in control } \\
\text { group) }\end{array}$ & $\begin{array}{l}\text { Decompression } \\
\text { and } \\
\text { posterolateral } \\
\text { fusion surgery at } \\
\text { the level of } \\
\text { spondylolisthesis }\end{array}$ & $\begin{array}{l}\text { Single-level } \\
\text { PLIF }\end{array}$ & $\begin{array}{l}\text { Lumbar interbody } \\
\text { fusion surgery } \\
\text { (with } 23 \text { one level, } \\
9 \text { two levels in } \\
\text { BPs group, } 24 \text { one } \\
\text { level, } 8 \text { two levels } \\
\text { in control group) }\end{array}$ & Single-level PLIF & TLIF \\
\hline $\begin{array}{l}\text { Number of } \\
\text { patients in } \\
\text { BPs/control } \\
\text { group }\end{array}$ & 19/17 & $41 / 41$ & $20 / 22$ & $22 / 22$ & $32 / 32$ & $33 / 36$ & $30 / 34$ \\
\hline $\begin{array}{l}\text { Number of } \\
\text { male } \\
\text { patients in } \\
\text { BPs/control } \\
\text { group }\end{array}$ & $1 / 1$ & $13 / 16$ & $0 / 0$ & 9 & $5 / 6$ & $6 / 7$ & $3 / 4$ \\
\hline $\begin{array}{l}\text { Diseases } \\
\text { type and } \\
\text { number of } \\
\text { diseases in } \\
\text { BPs/control } \\
\text { group }\end{array}$ & $\begin{array}{l}\text { Degenerative } \\
\text { spondylolisthesis (15), } \\
\text { isthmic } \\
\text { spondylolisthesis (1), } \\
\text { foraminal stenosis (3)/ } \\
\text { degenerative } \\
\text { spondylolisthesis (14), } \\
\text { isthmic } \\
\text { spondylolisthesis (1), } \\
\text { foraminal stenosis (2) }\end{array}$ & $\begin{array}{l}\text { Degenerative disc } \\
\text { disease alone (26), } \\
\text { isthmic or } \\
\text { degenerative } \\
\text { spondylolisthesis (12), } \\
\text { recurrent disc } \\
\text { herniations (3)/ } \\
\text { degenerative disc } \\
\text { disease alone (25), } \\
\text { isthmic or } \\
\text { degenerative } \\
\text { spondylolisthesis (14), } \\
\text { recurrent disc } \\
\text { herniations (2) }\end{array}$ & $\begin{array}{l}\text { Lumbar } \\
\text { degenerative } \\
\text { spondylolisthesis } \\
\text { with spinal } \\
\text { stenosis }\end{array}$ & - & $\begin{array}{l}\text { Degenerative } \\
\text { lumbar } \\
\text { spondylolisthesis }\end{array}$ & $\begin{array}{l}\text { Single-level } \\
\text { degenerative } \\
\text { spondylolisthesis } \\
\text { and diagnosis of } \\
\text { osteoporosis }\end{array}$ & - \\
\hline $\begin{array}{l}\text { Number of } \\
\text { operative } \\
\text { levels in BPs/ } \\
\text { control } \\
\text { group }\end{array}$ & $\begin{array}{l}\text { L3-4 (1), L4-5 (14), L5- } \\
\text { S1 (4)/L2-3 (1), L3-4 (3), } \\
\text { L4-5 (12), L5-S1 (1) }\end{array}$ & $\begin{array}{l}\text { L2-3 (1), L3-4 (7), L4-5 } \\
\text { (27), L5-S1 (26)/L2-3 } \\
\text { (1), L3-4 (5), L4-5 (31), } \\
\text { L5-S1 (25) }\end{array}$ & - & - & - & $\begin{array}{l}\text { L4-5 (24), L5-S1 } \\
(9) / L 4-5(25), \text { L5- } \\
\text { S1 (11) }\end{array}$ & - \\
\hline $\begin{array}{l}\text { Mean age of } \\
\text { patients in } \\
\text { BPs/control } \\
\text { group }\end{array}$ & $70.2 / 67.4$ & $\begin{array}{l}63.63 \text { (SE 6.36)/63.83 } \\
\text { (SE 5.70) }\end{array}$ & $\begin{array}{l}75(\mathrm{SD} 5) / 77 \text { (SD } \\
5.8)\end{array}$ & $\begin{array}{l}64.7 \text { (range } \\
60-74 \text { ) }\end{array}$ & $\begin{array}{l}70.8(S D \text { 6.09)/69.7 } \\
\text { (SD 6.02) }\end{array}$ & $\begin{array}{l}65(\mathrm{SD} 8) / 63(\mathrm{SD} \\
7)\end{array}$ & $\begin{array}{l}64.53(S D \\
6.86) / 66.44 \\
(S D 6.44)\end{array}$ \\
\hline $\begin{array}{l}\text { Mean BMl of } \\
\text { patients in } \\
\text { BPs/control } \\
\text { group }\end{array}$ & - & $\begin{array}{l}23.01 \text { (SE 3.53)/22.76 } \\
\text { (SE 3.54) }\end{array}$ & - & - & $\begin{array}{l}31(\mathrm{SD} 2.1) / 30(\mathrm{SD} \\
1.8)\end{array}$ & & $\begin{array}{l}23.98(S D \\
2.32) / 24.12 \\
(S D 2.07)\end{array}$ \\
\hline $\begin{array}{l}\text { Intervention } \\
\text { methods in } \\
\text { BPs/control } \\
\text { group }\end{array}$ & $\begin{array}{l}\text { Alendronate sodium } \\
35 \mathrm{mg} \text { per week/ } \\
\text { alfacalcidol } 1 \mathrm{mg} \text { per } \\
\text { day }\end{array}$ & $\begin{array}{l}\text { An infusion of ZOL ( } 5 \\
\text { mg, } 100 \text { ml) or } \\
\text { physiological saline } \\
\text { (100 ml) was } \\
\text { administered } 3 \text { days } \\
\text { after the surgery. }\end{array}$ & $\begin{array}{l}\text { Risedronate } 2.5 \\
\text { mg per day for } \\
10 \text { months/no } \\
\text { medication }\end{array}$ & $\begin{array}{l}\text { Alendronate } \\
\text { sodium } 35 \\
\text { mg per } \\
\text { week/no } \\
\text { medication }\end{array}$ & $\begin{array}{l}\text { Zoledronate } 5 \mathrm{mg} \\
\text { IV infusion } 3 \mathrm{~d} \\
\text { after surgery and } \\
\text { once-yearly there- } \\
\text { after/no } \\
\text { medication }\end{array}$ & $\begin{array}{l}\text { Zoledronic acid } \\
\text { infusion }(5 \mathrm{mg}) \text {, } \\
\text { or the same } \\
\text { volume of saline } \\
\text { after surgery. }\end{array}$ & $\begin{array}{l}\text { Intravenous } \\
\text { zoledronic } \\
\text { acid } 5 \mathrm{mg} \\
\text { at 3rd-5th } \\
\text { days after } \\
\text { operation/ } \\
\text { no } \\
\text { medication }\end{array}$ \\
\hline $\begin{array}{l}\text { Background } \\
\text { treatment }\end{array}$ & - & $\begin{array}{l}\text { Calcium }(1,000 \mathrm{mg} / \\
\text { day) and vitamin D } \\
\text { (400 IU/day) orally }\end{array}$ & - & - & - & $\begin{array}{l}\text { Daily } 1000 \mathrm{mg} \\
\text { calcium and } 800 \\
\text { IU vitamin D }\end{array}$ & $\begin{array}{l}\text { Oral calcium } \\
600 \mathrm{mg} \text { and } \\
\text { vitamin D } \\
800 \mathrm{IU}\end{array}$ \\
\hline $\begin{array}{l}\text { Preoperative } \\
\text { lumbar spine }\end{array}$ & $-1.9 /-2.2$ & $\begin{array}{l}\text { Less than }-1.5(7) \text {, } \\
-1.5 \text { to }-2.5(14) \text {, no }\end{array}$ & - & $-3.75 /-3.98$ & $\begin{array}{l}-3.1(\mathrm{SD} 0.59) / \\
-2.9(\mathrm{SD} 0.5)\end{array}$ & $\begin{array}{l}\text { BMD of lumbar } \\
\text { spine (L1-4) }\end{array}$ & - \\
\hline
\end{tabular}


Table 1 Characteristics of the 7 included studies (Continued)

\begin{tabular}{|c|c|c|c|c|c|c|c|}
\hline First author & Ken Nagahama & Chao Li & Seiji Ohtori & $\begin{array}{l}\text { Sang-Mok } \\
\text { Kim }\end{array}$ & Chao-Wei Tu & Fei Chen & Qirui Ding \\
\hline $\begin{array}{l}\text { BMD t-score } \\
\text { in BPs/con- } \\
\text { trol group }\end{array}$ & & $\begin{array}{l}\text { less than }-2.5(20) / \\
\text { less than }-1.5(9), \\
-1.5 \text { to }-2.5(13), \text { no } \\
\text { less than }-2.5(19)\end{array}$ & & & & $\begin{array}{l}0.709(\mathrm{SD} \\
0.003) \mathrm{g} / \mathrm{cm}^{2} / \\
0.698(\mathrm{SD} \\
0.004) \mathrm{g} / \mathrm{cm}^{2}\end{array}$ & \\
\hline $\begin{array}{l}\text { Preoperative } \\
\text { mean ODI } \\
\text { scores in } \\
\text { BPs/control } \\
\text { group }\end{array}$ & 20.3/21.6 & - & $\begin{array}{l}36 \text { (SD 10)/40 } \\
(\mathrm{SD} 10)\end{array}$ & - & $\begin{array}{l}63.5(\mathrm{SD} 6.3) / 64 \\
\text { (SD 5.67) }\end{array}$ & $\begin{array}{l}20.8(S D 2.6) / 21.9 \\
(S D 2.6)\end{array}$ & $\begin{array}{l}39.2(S D \\
2.27) / 38.7 \\
(S D 2.69)\end{array}$ \\
\hline $\begin{array}{l}\text { Mean follow- } \\
\text { up duration }\end{array}$ & 12 months & 12 months & 1 year & 33.8 months & 24 months & 1 year & 30 months \\
\hline
\end{tabular}

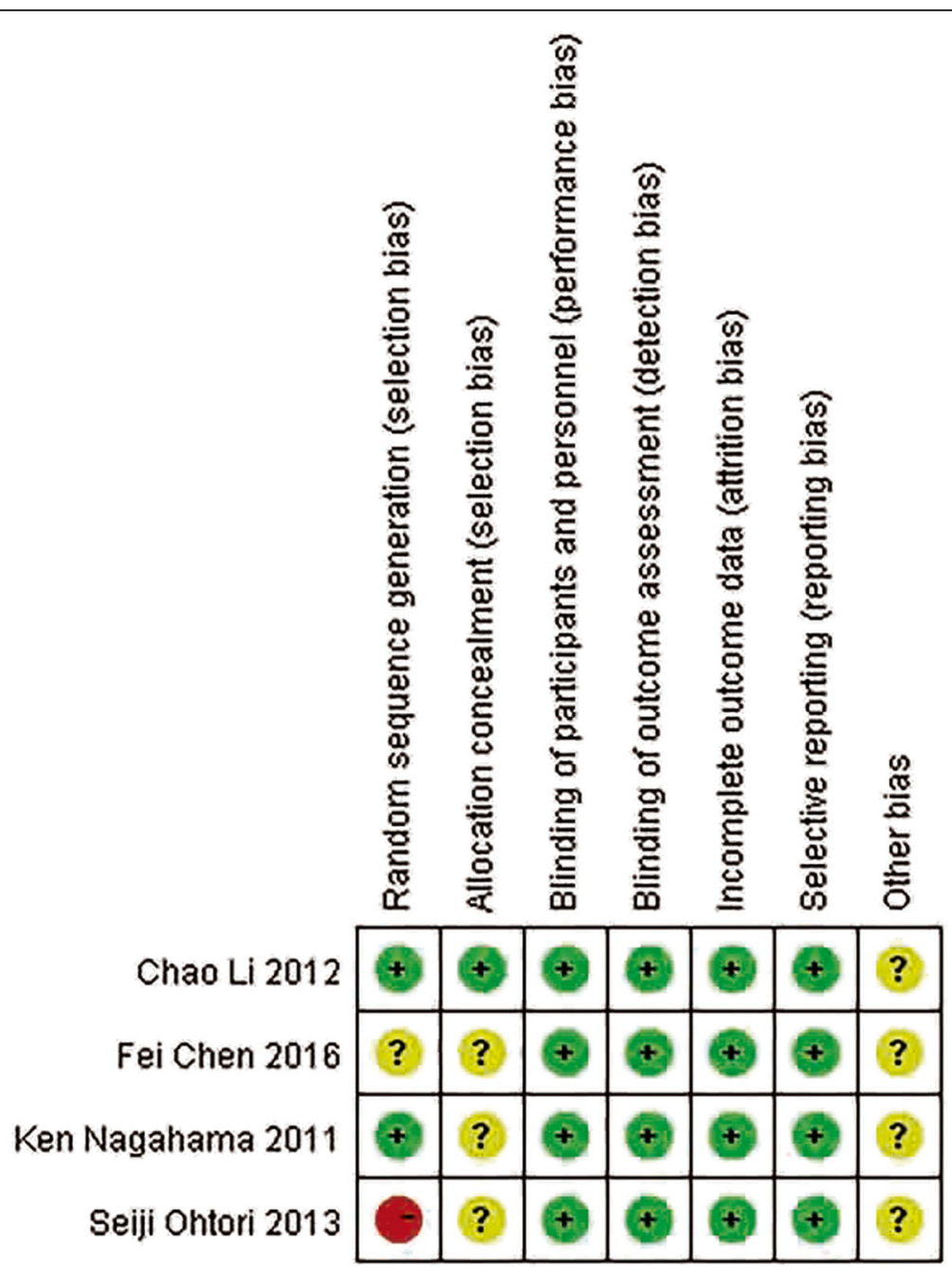

Fig. 2 Risk of bias summary for included RCTs 
Table 2 Quality assessment of the included cohort trials

\begin{tabular}{|c|c|c|c|}
\hline & \multicolumn{3}{|l|}{ Study (year) } \\
\hline & Sang-Mok Kim (2014) & Chao-Wei Tu (2014) & Qirui Ding (2017) \\
\hline \multicolumn{4}{|l|}{ Selection } \\
\hline Representativeness of the exposed cohort & * & * & * \\
\hline Ascertainment of exposure & * & * & * \\
\hline Outcome not present at the start of the study & * & * & * \\
\hline \multicolumn{4}{|l|}{ Comparability } \\
\hline Comorbidities & * & & \\
\hline Other factors & * & * & * \\
\hline \multicolumn{4}{|l|}{ Outcome } \\
\hline Assessment of the outcome & * & * & * \\
\hline Follow-up long enough for the outcome to occur & * & * & * \\
\hline Adequacy of the follow-up & * & * & * \\
\hline Total & 8 & 7 & 7 \\
\hline
\end{tabular}

controlled trials (RCTs) and other comparative cohort studies.

\section{Materials and methods Search strategy}

Two trained investigators systematically searched major online databases, including PubMed, EMBASE, the Web of Science, and the Cochrane Central Register of Controlled Trials, on July 13, 2020. The following terms were used while searching the databases and were arranged in different combinations: "interbody fusion", "lumbar fusion", "spinal fusion", "bisphosphonate", "alendronate", "clodronate", "etidronate", "ibandronate", "minodronate", "neridronate", "olpadronate", "pamidronate", "risedronate", "tiludronic acid", and "zoledronic acid".

\section{Study identification and eligibility criteria}

Two trained investigators independently screened the titles and abstracts in the electronic databases to identify possible eligible studies. Subsequently, the full text was read to include the final studies that met the following criteria: (1) candidates: patients who experienced any type of lumbar fusion surgery; (2) intervention: BP treatment with or without calcium and vitamin D supplements after surgery served as the experimental group, and placebo or standard treatment plus calcium and vitamin D supplements served as the control group; (3) outcome: desirable parameters that described surgical effects, including the fusion rate, vertebral compression fracture, bone formation grade, and other parameters; (4) type of studies: RCTs or comparative cohort studies; and (5) language of publication: English articles.

\section{Data extraction and assessment of risk of bias}

The following data were extracted from the included studies by the two investigators mentioned above: name of the first author, publication year, study location, surgical methods, number of subjects allocated to each group, lumbar diseases and surgical levels in each study, number of male subjects in each group, mean age and body mass index (BMI) of each group, intervention methods used in each group, background treatment, preoperative lumbar spine BMD $\mathrm{t}$-score in each group, preoperative Oswestry disability index (ODI) in each group, and follow-up duration. Any existing disagreement was resolved by discussion with a third investigator. The Cochrane risk of bias tool and the Newcastle-Ottawa Scale were used to assess the methodological quality of RCTs, and retrospective or prospective cohort studies, respectively $[26,27]$.

Table 3 Results of the forest plots for the bone formation grade at the 12-month follow-up

\begin{tabular}{|c|c|c|c|c|c|c|c|c|}
\hline Bone formation grade at the 12 -month follow-up & $\begin{array}{l}\text { Number of } \\
\text { patients }\end{array}$ & $\begin{array}{l}\text { Number of included } \\
\text { studies }\end{array}$ & OR & $\begin{array}{l}95 \% \\
\mathrm{Cl}\end{array}$ & $\begin{array}{l}P \\
\text { value }\end{array}$ & $x^{2}$ & $I^{2}$ & $\begin{array}{l}\text { Effect } \\
\text { model }\end{array}$ \\
\hline $\begin{array}{l}\text { Number of patients with bone formation grade } A \text { at } 12 \\
\text { months of follow-up }\end{array}$ & 105 & 2 & 1.32 & $\begin{array}{l}0.61 \\
2.86\end{array}$ & 0.48 & 0.49 & $0 \%$ & $\begin{array}{l}\text { Random } \\
\text { effect }\end{array}$ \\
\hline $\begin{array}{l}\text { Number of patients with bone formation grade } B \text { at } 12 \\
\text { months of follow-up }\end{array}$ & 105 & 2 & 1.13 & $\begin{array}{l}0.46 \\
2.75\end{array}$ & 0.79 & 0.33 & $0 \%$ & $\begin{array}{l}\text { Random } \\
\text { effect }\end{array}$ \\
\hline $\begin{array}{l}\text { Number of patients with bone formation grade } C \text { at } 12 \\
\text { months of follow-up }\end{array}$ & 105 & 2 & 0.41 & $\begin{array}{l}0.04 \\
4.20\end{array}$ & 0.45 & 0.07 & $71 \%$ & $\begin{array}{l}\text { Random } \\
\text { effect }\end{array}$ \\
\hline
\end{tabular}


Table 4 Results of the forest plots for the fusion rates at the 12- and 24-month follow-ups

\begin{tabular}{lllllllll}
\hline Fusion rate & Number of patients & Number of included studies & OR & $\mathbf{9 5 \%} \mathbf{C l}$ & $\boldsymbol{P}$ value & $\boldsymbol{X}^{\mathbf{2}}$ & $\boldsymbol{I}^{\mathbf{2}}$ & Effect model \\
\hline Fusion rate at the 12-month follow-up & 338 & 4 & 1.55 & $0.76,3.17$ & 0.23 & 0.32 & $14 \%$ & Random effect \\
Fusion rate at the 24-month follow-up & 108 & 2 & 1.47 & $0.52,4.13$ & 0.47 & 0.21 & $36 \%$ & Random effect
\end{tabular}

\section{Statistical analysis}

The two investigators identified and recorded the following outcome parameters: number of patients with bone formation grades $\mathrm{A}, \mathrm{B}$, and $\mathrm{C}$ at 12 months of follow-up, fusion rates at 12 and 24 months of follow-up, vertebral compression fracture (VCF) at 12 and 24 months of follow-up, pedicle screw loosening at 24 months of follow-up, and cage subsidence, ODI, and visual analogue score (VAS) at 12 months of follow-up.

The statistical analysis was performed using RevMan 5.3 software. Odds ratios (OR) plus 95\% confidence intervals (CIs) (calculated using a random effects model) and the mean differences (MD) plus 95\% CIs (calculated using a fixed effects model) were calculated for dichotomous variables and continuous outcomes, respectively. $P<0.05$ was deemed statistically significant. Chi-square $\left(\chi^{2}\right)$ and $I^{2}$ tests were used to identify heterogeneity, with $p<0.05$ and $I^{2}>50 \%$ considered indicators of heterogeneity. If heterogeneity in continuous outcomes existed, a random effects model was applied.

\section{Results}

\section{Literature search}

Ninety-six titles were identified using our search terms, and duplicate articles were removed. Subsequently, 75 studies were eliminated after reading the titles and abstracts, leaving 21 trials for the full-text review. After reading the full text, 14 articles were excluded since their full text was not published in English or their comparison items did not meet the requirements. Finally, 7 articles were included in this meta-analysis [6, 19, 2832] (Fig. 1).

\section{Study characteristics}

Table 1 provides detailed information on the 7 included studies. The studies were published from 2011 to 2019. Four studies were RCTs [6, 19, 28-32], and 3 studies were retrospective comparative cohort studies [19, 29, 32]. The sample size ranged from 17 to 62 patients. Four hundred ninety-six patients with a mean age ranging from 63.63 to 77 years were included. One study did not mention the specific type of BPs used in their study. The shortest follow-up duration was 12 months, while the longest was 33.8 months.

\section{Study quality}

The methodological quality of all included RCTs was high (Fig. 2), with a low risk of bias considered for most terms. All included cohort studies scored greater than 6 (Table 2), indicating a relatively high quality.

According to Egger et al. [33], applying a funnel plot to assess publication bias is not credible for a metaanalysis that included fewer than 10 studies. Therefore, funnel plot was not used in this meta-analysis.

\section{Bone formation grade at the 12-month follow-up}

The numbers of patients with bone formation grades $\mathrm{A}$, $\mathrm{B}$, and $\mathrm{C}$ were reported by more than one study. Table 3 shows the results of the forest plots, which indicated that BPs did not significantly influence bone formation grades $\mathrm{A}, \mathrm{B}$, and $\mathrm{C}$ at the 12-month follow-up compared with the control treatments. Random effect model was used to solve the heterogeneity.

\section{Fusion rates at the 12- and 24-month follow-ups}

Fusion rates at the 12- and 24-month follow-ups were provided reported by more than one study. Table 4 shows the results of the meta-analysis, which suggests that compared with the control treatments, BPs did not clearly alter influence the fusion rates at the 12- and 24month follow-ups.

\section{Number of patients with VCF at the 12- and 24-month follow-ups}

The number of patients with VCF was reported by more than one study. Table 5 shows the results of the forest plots. Compared with the control treatments, BPs significantly reduced the risks of VCF at the 12 - and 24month follow-up visits.

Table 5 Results of the forest plots for the number of patients with VCF at the 12- and 24-month follow-ups

\begin{tabular}{|c|c|c|c|c|c|c|c|c|}
\hline Number of patients with VCF & $\begin{array}{l}\text { Number of } \\
\text { patients }\end{array}$ & $\begin{array}{l}\text { Number of included } \\
\text { studies }\end{array}$ & OR & $95 \% \mathrm{Cl}$ & $\begin{array}{l}P \\
\text { value }\end{array}$ & $x^{2}$ & $I^{2}$ & $\begin{array}{l}\text { Effect } \\
\text { model }\end{array}$ \\
\hline $\begin{array}{l}\text { Number of patients with VCF at the 12-month } \\
\text { follow-up }\end{array}$ & 105 & 2 & 0.07 & $\begin{array}{l}0.01 \\
0.59\end{array}$ & 0.01 & 0.96 & $0 \%$ & $\begin{array}{l}\text { Random } \\
\text { effect }\end{array}$ \\
\hline $\begin{array}{l}\text { Number of patients with VCF at 24-month follow- } \\
\text { up }\end{array}$ & 128 & 2 & 0.20 & $\begin{array}{l}0.07 \\
0.58\end{array}$ & 0.003 & 0.54 & $0 \%$ & $\begin{array}{l}\text { Random } \\
\text { effect }\end{array}$ \\
\hline
\end{tabular}




\begin{tabular}{|c|c|c|c|c|c|c|c|c|c|c|c|}
\hline Study or Subgroup & $\begin{array}{l}\text { BPs } \\
\text { Events }\end{array}$ & Total & $\begin{array}{l}\text { Contr } \\
\text { Events }\end{array}$ & $\begin{array}{l}\text { ol } \\
\text { Total }\end{array}$ & Weight & $\begin{array}{l}\text { Odds Ratio } \\
\text { M. } \mathrm{H} \text {, Random. } 95 \% \mathrm{Cl}\end{array}$ & Year & & $\begin{array}{r}\text { Odds } \\
\text { M.H, Rand }\end{array}$ & $\begin{array}{l}\text { Ratio } \\
\text { om. } 95 \% \mathrm{Cl}\end{array}$ & \\
\hline Chao-Wei Tu 2014 & 6 & 32 & 14 & 32 & $87.0 \%$ & $0.30[0.10,0.92]$ & 2014 & & -1 & & \\
\hline Qirui Ding 2017 & 0 & 30 & 6 & 34 & $13.0 \%$ & $0.07[0.00,1.33]$ & 2017 & $\longleftarrow$ & & & \\
\hline Total $(95 \% \mathrm{Cl})$ & & 62 & & 66 & $100.0 \%$ & $0.25[0.09,0.71]$ & & & & & \\
\hline Total events & 6 & & 20 & & & & & & & & \\
\hline \multicolumn{8}{|c|}{$\begin{array}{l}\text { Heterogeneity: Tau }{ }^{2}=0.00 ; \text { Chi }^{2}=0.84, d f=1(P=0.36) ; l^{2}=0 \% \\
\text { Test for overall effect: } Z=2.60(P=0.009)\end{array}$} & 0.01 & $\begin{array}{l}0.1 \\
\text { Favours [BPs] }\end{array}$ & $\begin{array}{l}10 \\
\text { Favours [control] }\end{array}$ & 100 \\
\hline
\end{tabular}

Fig. 3 Forest plot showing the number of patients with pedicle screw loosening at the 24-month follow-up

\section{Number of patients with pedicle screw loosening at the 24-month follow-up}

The number of patients with pedicle screw loosening at the 24-month follow-up was reported by more than one study. As shown in Fig. 3, compared with control treatments, BPs significantly reduced the risks of pedicle screw loosening at the 24-month follow-up.

\section{Number of patients with cage subsidence}

The number of patients with cage subsidence was described by more than one study. As shown in Fig. 4, compared with the control treatments, BPs significantly reduced the incidence of cage subsidence.

\section{ODI and VAS at the 12-month follow-up}

The ODI and VAS at the 12-month follow-up were provided by more than one study. In Table 6, BPs did not noticeably alter the ODI and VAS compared with the control treatment. Random effect models were applied to solve the heterogeneity.

\section{Subgroup analysis for RCTs and non-RCTS}

Because the level of evidence is quite different between RCTs and non-RCTs, we separated the results of forest plots into RCTs and non-RCTs. Table 7 indicates that nearly all results were similar to those of the metaanalysis for both RCTs and non-RCTs, with the exception of the ODI score, which presents higher heterogeneity than that of the overall meta-analysis. A random effect model was used to solve the heterogeneity.

\section{Sensitivity analysis}

We conducted a sensitivity analysis to identify the source of heterogeneity in the comparison of the ODI between groups at the 12-month follow-up (Fig. 5). Due to the type of BPs, ratio of female patients, and age of patients, we omitted the study conducted by Ohtori et al., and the heterogeneity was clearly decreased and the result changed significantly. As shown in the forest plot, BPs clearly reduced the ODI at the 12-month follow-up compared with the control treatment.

\section{Discussion}

Overall, the forest plots shown above suggest that compared with the placebo, BP treatment did not significantly alter the number of patients with bone formation grades $\mathrm{A}, \mathrm{B}$ and $\mathrm{C}$, or the VAS at the 12-month followup or the fusion rates at the 12- and 24-month followups. In addition, compared with the placebo, BPs significantly reduced the risks of VCF at the 12- and 24month follow-ups, pedicle screw loosening at the 24month follow-up, and cage subsidence and the ODI at the 12-month follow-up.

Since the mechanism of BPs involves the inhibition of bone resorption, the BP treatment might modify the remodelling process associated with spinal fusion [34]. However, although a BP treatment increases bone formation after lumbar spinal fusion surgery in animal studies, the fusion rate is reduced [35-37]. In contrast, several clinical studies have documented positive results for the effect of BP treatment on bone formation and the fusion rate $[6,29]$, although a recent study observed

\begin{tabular}{|c|c|c|c|c|c|c|c|c|c|c|c|}
\hline Studv or Subgroun & $\begin{array}{l}\text { BPs } \\
\text { Events }\end{array}$ & Total & $\begin{array}{l}\text { Contr } \\
\text { Events }\end{array}$ & Total & Weight & $\begin{array}{c}\text { Odds Ratio } \\
\text { M.H. Random. } 95 \% \mathrm{Cl}\end{array}$ & Year & \multicolumn{4}{|c|}{$\begin{array}{c}\text { Odds Ratio } \\
\text { M.H. Random. } 95 \% \mathrm{Cl}\end{array}$} \\
\hline Ken Nagahama 2011 & 1 & 19 & 5 & 17 & $17.3 \%$ & $0.13[0.01,1.29]$ & 2011 & & & $F$ & \\
\hline Chao-Wei Tu 2014 & 9 & 32 & 17 & 32 & $82.7 \%$ & $0.35[0.12,0.97]$ & 2014 & & & & \\
\hline Total $(95 \% \mathrm{CI})$ & & 51 & & 49 & $100.0 \%$ & $0.29[0.11,0.75]$ & & & & & \\
\hline Total events & 10 & & 22 & & & & & & & & \\
\hline $\begin{array}{l}\text { Heterogeneity: } \text { Tau }^{2}= \\
\text { Test for overall effect: } 2\end{array}$ & $\begin{array}{l}00 ; \mathrm{Ch}^{2}= \\
=2.55(\mathrm{P}=\end{array}$ & $\begin{array}{l}=0.56,0 \\
=0.01)\end{array}$ & $\mathrm{df}=1(\mathrm{P}=$ & $=0.45) ;$ & $i^{2}=0 \%$ & & & 0.01 & $\begin{array}{l}0.1 \\
\text { Favours [BPs] }\end{array}$ & $10 \frac{10}{\text { Favours [control] }}$ & 100 \\
\hline
\end{tabular}


Table 6 Results of the forest plots for the ODI and VAS

\begin{tabular}{|c|c|c|c|c|c|c|c|c|}
\hline Parameters & Number of patients & Number of included studies & MD & $95 \% \mathrm{Cl}$ & $P$ value & $x^{2}$ & $I^{2}$ & Effect model \\
\hline ODI at the 12-month follow-up & 175 & 3 & -1.98 & $-4.68,0.72$ & 0.15 & 0.10 & $56 \%$ & $\overline{\text { Random effect }}$ \\
\hline VAS at 12-month follow-up & 106 & 2 & -0.34 & $-1.12,0.44$ & 0.39 & 0.05 & $74 \%$ & Random effect \\
\hline
\end{tabular}

a low fusion rate in patients with long-term BP treatment [20]. Our forest plots indicated no clear difference in bone formation and the fusion rate between patients treated with BPs and the control treatment. A study conducted by Nagahama et al. showed a positive effect of BP treatment on bone formation grade $\mathrm{C}$ and the $\mathrm{fu}-$ sion rate at the 12-month follow-up; the BP they used was alendronate. Another study that used alendronate was conducted by Kim et al., who did not observe a positive effect on the fusion rate at the 24-month followup; therefore, the type of drug may not have caused the positive result, and the follow-up time point may also have contributed $[6,19]$. The reason for the negative results may be that although BPs inhibit bone resorption, they also in turn inhibit bone remodelling and may remain callus but may delay final remodelled-bone union. In addition, a study also suggested that BPs have potential antiangiogenic effects and reduce the blood supply at the fusion site [38]. The controversial conclusions regarding the effect of BPs on lumbar fusion among previous studies may result from different equivalent points of bone resorption and formation that BPs influenced in each study. Further studies are needed to confirm our hypothesis and results.

Osteoporosis-associated bone fragility (such as VCF and cage subsidence) and loosening of pedicle screws are the primary reasons for spinal fusion failure $[8,9$, 39]. Although BP treatment did not significantly alter bone formation and the fusion rate, our forest plots suggested that the BP treatment significantly reduced the risks of VCF at the 12- and 24-month follow-ups and pedicle screw loosening at the 12-month follow-up. Therefore, BP treatment might exert a positive effect on these two complications. Two included studies provided detailed information about the number of patients with cage subsidence $[6,32]$. Although the forest plot showed a positive result for BP treatment, the follow-up duration was not consistent between the two studies; therefore, the result may have also been influenced by the followup period. Nevertheless, in another study that compared alendronate and placebo, the researchers clearly observed a reduced length of cage subsidence in patients who received L4-5 lateral transpsoas interbody fusion [40]. However, due to the small sample size and use of

Table 7 Results of the forest plots for the subgroup analysis for RCTs and non-RCTs

\begin{tabular}{|c|c|c|c|c|c|c|c|c|c|}
\hline $\begin{array}{l}\text { Type of } \\
\text { study }\end{array}$ & Comparative parameters & $\begin{array}{l}\text { Number of } \\
\text { patients }\end{array}$ & $\begin{array}{l}\text { Number of } \\
\text { included studies }\end{array}$ & OR & $\begin{array}{l}95 \% \\
\mathrm{Cl}\end{array}$ & $\begin{array}{l}P \\
\text { value }\end{array}$ & $x^{2}$ & $P^{2}$ & $\begin{array}{l}\text { Effect } \\
\text { model }\end{array}$ \\
\hline \multicolumn{10}{|l|}{ RCTs } \\
\hline & $\begin{array}{l}\text { Number of patients with bone formation grade } A \\
\text { at } 12 \text { months of follow-up }\end{array}$ & 105 & 2 & 1.32 & $\begin{array}{l}0.61 \\
2.86\end{array}$ & 0.48 & 0.49 & $0 \%$ & $\begin{array}{l}\text { Random } \\
\text { effect }\end{array}$ \\
\hline & $\begin{array}{l}\text { Number of patients with bone formation grade B } \\
\text { at } 12 \text { months of follow-up }\end{array}$ & 105 & 2 & 1.13 & $\begin{array}{l}0.46 \\
2.75\end{array}$ & 0.79 & 0.33 & $0 \%$ & $\begin{array}{l}\text { Random } \\
\text { effect }\end{array}$ \\
\hline & $\begin{array}{l}\text { Number of patients with bone formation grade } C \\
\text { at } 12 \text { months of follow-up }\end{array}$ & 105 & 2 & 0.41 & $\begin{array}{l}0.04 \\
4.20\end{array}$ & 0.45 & 0.07 & $71 \%$ & $\begin{array}{l}\text { Random } \\
\text { effect }\end{array}$ \\
\hline & Fusion rate at the 12-month follow-up & 228 & 3 & 1.61 & $\begin{array}{l}0.56 \\
4.67\end{array}$ & 0.38 & 0.18 & $42 \%$ & $\begin{array}{l}\text { Random } \\
\text { effect }\end{array}$ \\
\hline & $\begin{array}{l}\text { Number of patients with VCF at the 12-month } \\
\text { follow-up }\end{array}$ & 105 & 2 & 0.07 & $\begin{array}{l}0.01 \\
0.59\end{array}$ & 0.01 & 0.96 & $0 \%$ & $\begin{array}{l}\text { Random } \\
\text { effect }\end{array}$ \\
\hline & $\mathrm{ODI}$ at the 12-month follow-up & 111 & 2 & -1.61 & $\begin{array}{l}-5.88 \\
2.67\end{array}$ & 0.46 & 0.03 & $78 \%$ & $\begin{array}{l}\text { Random } \\
\text { effect }\end{array}$ \\
\hline \multicolumn{10}{|c|}{ Non-RCTs } \\
\hline & Fusion rate at the 12-month follow-up & 179 & 2 & 1.26 & $\begin{array}{l}0.52, \\
3.05\end{array}$ & 0.62 & 0.46 & $0 \%$ & $\begin{array}{l}\text { Random } \\
\text { effect }\end{array}$ \\
\hline & Fusion rate at the 24-month follow-up & 108 & 2 & 1.47 & $\begin{array}{l}0.52 \\
4.13\end{array}$ & 0.47 & 0.21 & $36 \%$ & $\begin{array}{l}\text { Random } \\
\text { effect }\end{array}$ \\
\hline & $\begin{array}{l}\text { Number of patients with VCF at 24-month follow- } \\
\text { up }\end{array}$ & 128 & 2 & 0.20 & $\begin{array}{l}0.07 \\
0.58\end{array}$ & 0.003 & 0.54 & $0 \%$ & $\begin{array}{l}\text { Random } \\
\text { effect }\end{array}$ \\
\hline & $\begin{array}{l}\text { Number of patients with pedicle screw loosening } \\
\text { at the 24-month follow-up }\end{array}$ & 128 & 2 & 0.25 & $\begin{array}{l}0.09 \\
0.71\end{array}$ & 0.009 & 0.36 & $0 \%$ & $\begin{array}{l}\text { Random } \\
\text { effect }\end{array}$ \\
\hline
\end{tabular}




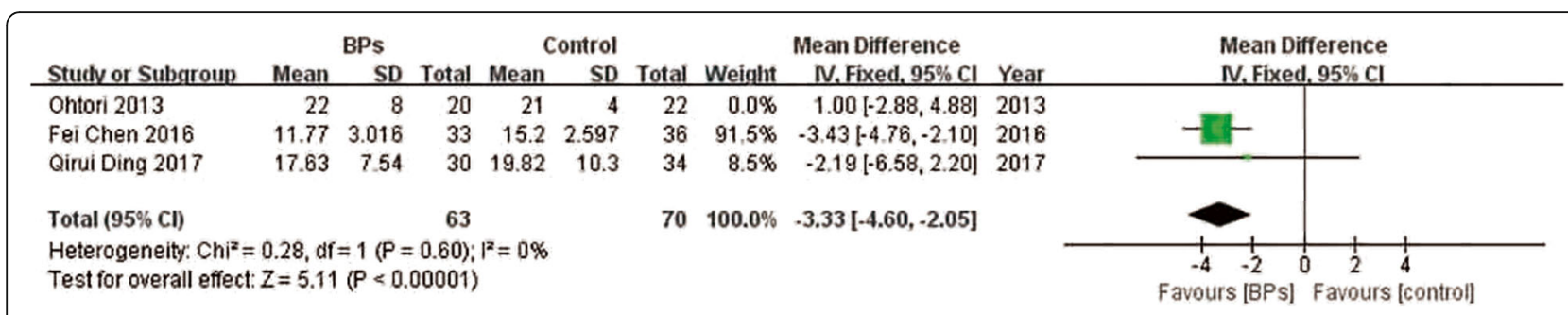

Fig. 5 Results of the sensitivity analysis for the ODI at the 12-month follow-up. The study by Ohtori et al. was omitted, and the conclusions from the forest plot clearly changed. The forest plot shows that compared with the control treatment, BPs noticeably reduced the ODI at the 12-month follow-up

different statistical methods, we were unable to conduct a meta-analysis on cage subsidence, and further studies are needed to explore these fields.

The ODI measures the degree of disability and estimates quality of life in a person with low back pain, while the VAS is a parameter that evaluates the degree of pain. According to our meta-analysis, compared with the placebo, BPs did not significantly alter the ODI and VAS at the 12-month follow-up, and thus they did not clearly improve quality of life. The ODI result is consistent with three other included studies, which also showed no difference between the two groups $[6,20,30]$, and only one other included study indicated that BPs clearly reduced the ODI compared with control treatments [32]. Due to the lack of reporting of standard deviations in most studies, we were unable to conduct a metaanalysis that included these data. In addition, the heterogeneity of the two results was relatively high. In the sensitivity analysis, we omitted the study conducted by Ohtori et al. due to the type of BPs, female ratio and age instead of simply the study type, and the forest plot showed that BPs clearly reduced the ODI. Moreover, in the comparison of VAS at the 12-month follow-up, we were unable to conduct a sensitivity analysis and subgroup analysis due to the small sample size [29, 31], but the study conducted by Ding et al. showed a clear decrease in the VAS for patients treated with BPs, while the study conducted by Ohtori et al. showed a neutral result. The studies did not clearly determine whether the BP type, ratio of females, and age influenced the result. Further studies are needed to explore the effects of these parameters. Another clinical outcome that evaluated quality of life provided by included studies is Short Form 36 scores, which revealed a positive effect of BP treatment [29] and no clear difference [20], respectively. However, due to the small sample size, we were unable to perform a meta-analysis, and further studies are needed to explore the Short Form 36 scores. The mechanism of BPs includes an effect on osteoclasts. Two included studies described changes in two bone turnover markers, propeptides of type I collagen (PINP) and Ctelopeptide of type I collagen (CTX), and their results indicated that BPs inhibit both bone formation and resorption [28, 30]. One included study also indicated that the BMD of the femoral neck was clearly increased in the BP treatment group [28]. However, we were unable to perform a meta-analysis due to differences in expression and small sample sizes, and further studies are required in this area.

Compared with a previous meta-analysis [25], we compared more parameters to evaluate the effect of BP therapy on lumbar fusion surgery and obtained some new findings, which indicated that compared with controls, BPs can significantly reduce VCF, cage subsidence, and loosening of pedicle screws after lumbar fusion surgery. Although the quality of included studies was relatively high, but we should also take consider the limitations listed below. First, the BPs used in the included studies were either alendronate or zoledronic acid, and other BP treatments had no effect on the fusion rate after lumbar spinal fusion surgery. Second, the main limitation of this meta-analysis is the small number of included studies and RCTs in particular, which may decrease the strength of our forest plots. Additionally, as the number of included studies was less than 10, meta-regression analyses and funnel plots were unable to be performed. Moreover, due to the small sample size of patients from RCTs, the data from the retrospective cohort studies may have influenced our results. Third, the included patients were mostly from East Asia, which may limit the wide application of this study. Finally, only English articles were considered eligible, which may have resulted in selection bias.

\section{Conclusions}

Our meta-analysis of RCTs revealed that postoperative BPs do not clearly improve bone formation and the fusion rate, but they reduce VCF, cage subsidence, and loosening of pedicle screws after lumbar fusion surgery compared with the control treatment. In addition, the effect of BPs on the ODI and VAS remains inconclusive. Finally, the number of studies and RCTs included in our meta-analysis is small, and further RCTs involving larger 
sample sizes are required to confirm our results and provide additional evidence in this field.

\section{Abbreviations}

BPs: Bisphosphonates; BMD: Bone mass density; RCTs: Randomized controlled trials; BMI: Body mass index; ODI: Oswestry disability index; VCF: Vertebral compression fracture; VAS: Visual analogue score; OR: Odds ratios; Cls: Confidence intervals; MD: Mean differences; PLIF: Posterior lumbar interbody fusion; TLIF: Transforaminal lumbar interbody fusion; SD: Standard deviation

\section{Acknowledgements}

None

\section{Authors' contributions}

Jun Mei: designed the research, analysed the data, wrote and checked the paper. Xiaoxu Song: collected the data, analysed the data. Xiaoming Guan: designed the research, analysed the data. Dou Wu: designed the research. Junjie Wang: performed research, collected the data, analysed the data. Qiang Liu: designed the research. The authors read and approved the final manuscript.

\section{Funding}

This meta-analysis is supported by Applied Basic Research Project of Shanxi Province (201901D111406).

Availability of data and materials

As a meta-analysis, there are no patient data sets.

\section{Declarations}

Ethics approval and consent to participate

Not applicable

\section{Consent for publication}

Not applicable

\section{Competing interests}

The authors declare that they have no competing interests.

\section{Author details}

${ }^{1}$ Shanxi Medical University, Taiyuan, China. ${ }^{2}$ Shanxi Bethune Hospital, Shanxi Academy of Medical Science, No. 99, Longcheng Street, Taiyuan 030032, Shanxi Province, China. ${ }^{3}$ Qingdao University, Qingdao, China.

Received: 12 January 2021 Accepted: 22 April 2021

\section{Published online: 29 April 2021}

\section{References}

1. Chin-wern C. Peng P Failed back surgery syndrome. Pain Medicine. 2011; 12(1):577-606

2. Karsy M, Bisson EF. Surgical versus nonsurgical treatment of lumbar spondylolisthesis. Neurosurg Clin N Am. 2019;30(3):333-40.

3. Deyo RA, Gray DT, Kreuter W, Mirza S. Martin BI United States trends in lumbar fusion surgery for degenerative conditions. Spine. 2005;30(12):14415. https://doi.org/10.1097/01.brs.0000166503.37969.8a.

4. Katz J. Lumbar spinal fusion. Surgical rates, costs, and complications. Spine 1995;20(24 Suppl):78S-83S.

5. Hirsch BP, Unnanuntana A, Cunningham ME. Lane JM The effect of therapies for osteoporosis on spine fusion: a systematic review. Spine J. 2013;13(2):190-9. https://doi.org/10.1016/..spinee.2012.03.035.

6. Nagahama K, Kanayama M, Togawa D, Hashimoto T. Minami A Does alendronate disturb the healing process of posterior lumbar interbody fusion? A prospective randomized trial. J Neurosurg Spine. 2011;14(4):500-7. https://doi.org/10.3171/2010.11.SPINE10245.

7. Chin DK, Park JY, Yoon YS, Kuh SU, Jin BH, Kim KS, et al. Prevalence of osteoporosis in patients requiring spine surgery: incidence and significance of osteoporosis in spine disease. Osteoporos Int. 2007:18(9):1219-24. https:// doi.org/10.1007/s00198-007-0370-8.
8. Halvorson TL, Kelley LA, Thomas KA, Whitecloud TS. Cook SD Effects of bone mineral density on pedicle screw fixation. Spine. 1994;19(21):2415-20. https://doi.org/10.1097/00007632-199411000-00008.

9. Etebar S. Cahill DW Risk factors for adjacent-segment failure following lumbar fixation with rigid instrumentation for degenerative instability. J Neurosurg. 1999:90(2):163-9.

10. McCoy S, Tundo F, Chidambaram S. Baaj AA Clinical considerations for spinal surgery in the osteoporotic patient: a comprehensive review. Clin Neurol Neurosurg. 2019;180:40-7. https://doi.org/10.1016/j.clineuro.2019.03. 010.

11. Ebata S, Takahashi J, Hasegawa T, Mukaiyama K, Isogai Y, et al. Role of weekly teriparatide administration in osseous union enhancement within six months after posterior or transforaminal lumbar interbody fusion for osteoporosis-associated lumbar degenerative disorders: a multicenter, prospective randomized study. J Bone Joint Surg Am. 2017:99(5):365-72.

12. Russell RG, Mühlbauer RC, Bisaz $\mathrm{S}$, Williams DA. Fleisch $H$ The influence of pyrophosphate, condensed phosphates, phosphonates and other phosphate compounds on the dissolution of hydroxyapatite in vitro and on bone resorption induced by parathyroid hormone in tissue culture and in thyroparathyroidectomised rats. Calcif Tissue Res. 1970;6(3):183-96. https:// doi.org/10.1007/BF02196199.

13. Duque G. Osteoporosis in older persons: current pharmacotherapy and future directions. Expert Opin Pharmacother. 2013;14(14):1949-58. https:// doi.org/10.1517/14656566.2013.822861

14. Russell RG. Bisphosphonates: the first 40 years. Bone. 2011;49(1):2-19. https://doi.org/10.1016/j.bone.2011.04.022.

15. Drake MT, Clarke BL. Lewiecki EM The pathophysiology and treatment of osteoporosis. Clin Ther. 2015;37(8):1837-50. https://doi.org/10.1016/j. clinthera.2015.06.006

16. Kanis JA, Cooper C, Rizzoli R. Reginster JY Executive summary of the European guidance for the diagnosis and management of osteoporosis in postmenopausal women. Calcif Tissue Int. 2019;104(3):235-8. https://doi. org/10.1007/s00223-018-00512-x.

17. Gehrig L, Lane J. O'Connor Ml Osteoporosis: management and treatment strategies for orthopaedic surgeons. J Bone Joint Surg Am A. 2008;90(6): 1362-74.

18. Murad MH, Drake MT, Mullan RJ, Mauck KF, Stuart LM, Lane MA, et al. Clinical review. Comparative effectiveness of drug treatments to prevent fragility fractures: a systematic review and network meta-analysis. J Clin Endocrinol Metab. 2012;97(6):1871-80. https://doi.org/10.1210/jc.2011-3060.

19. Kim SM, Rhee W, Ha S, Lim JH. Jang IT Influence of alendronate and endplate degeneration to single level posterior lumbar spinal interbody fusion. Korean J Spine. 2014;11(4):221-6. https://doi.org/10.14245/kjs.2 014.11.4.221.

20. Kang T, Park SY, Hong SH, Lee JH. Park JH Bone union after spinal fusion surgery using local bone in long-term bisphosphonate users: a prospective comparative study. Arch Osteoporos. 2019;14(1):74. https://doi.org/10.1007/ s11657-019-0628-8.

21. Koo KH, Lee JH, Chang BS. Lee CK Effects of alendronate on lumbar posterolateral fusion using hydroxyapatite in rabbits. Artificial Organs. 2012;10(9):S27.

22. Nakao SI, Minamide A, Kawakami M, Boden SD, Yoshida M. The influence of alendronate on spine fusion in an osteoporotic animal model. Spine. 2011; 36(18):1446-52. https://doi.org/10.1097/BRS.0b013e3181f49c47.

23. Guppy KH, Chan PH, Prentice HA, Norheim EP, Harris JE, Brara HS. Does the use of preoperative bisphosphonates in patients with osteopenia and osteoporosis affect lumbar fusion rates? Analysis from a national spine registry. Neurosurg Focus. 2020;49(2):E12. https://doi.org/10.3171/2020.5. FOCUS20262.

24. Soldozy S, Sarathy D, Skaff A, Montgomery SR Jr, Young S, Desai B, et al. Pharmacologic considerations in patients with osteoporosis undergoing lumbar interbody fusion: a systematic review. Clin Neurol Neurosurg. 2020; 196:106030

25. Cheng SH, Kuo YJ, Chen C, Kang YN. Effects of teriparatide and bisphosphonate on spinal fusion procedure: a systematic review and network meta-analysis. PLoS One. 2020;15(9):e0237566.

26. Shuster JJ. Review: Cochrane handbook for systematic reviews for interventions, Version 5.1.0, published 3/2011. Julian P.T. Higgins and Sally Green, Editors. Res Synth Methods. 2011:2(2):126-30. https://doi.org/10.1 002/jrsm.38

27. Wells G, Shea B, O'Connell J. The Newcastle-Ottawa Scale (NOS) for Assessing The Quality of Nonrandomised Studies in Meta-analyses; 2014. 
28. Chen F, Dai Z, Kang Y, Lv G, Keller ET, Jiang Y. Effects of zoledronic acid on bone fusion in osteoporotic patients after lumbar fusion. Osteoporos Int. 2016;27(4):1469-76. https://doi.org/10.1007/s00198-015-3398-1.

29. Ding Q. Chen, Jian, Fan, et al. Effect of zoledronic acid on lumbar spinal fusion in osteoporotic patients. Eur Spine J. 2017;26(11):2969-77. https://doi. org/10.1007/s00586-017-5286-1.

30. Li C, Wang HR, Li XL, Zhou XG. Dong J The relation between zoledronic acid infusion and interbody fusion in patients undergoing transforaminal lumbar interbody fusion surgery. Acta Neurochirurgica. 2012;154(4):731-8. https://doi.org/10.1007/s00701-012-1283-7.

31. Ohtori S, Inoue G, Orita S, Yamauchi K, Eguchi Y, et al. Comparison of teriparatide and bisphosphonate treatment to reduce pedicle screw loosening after lumbar spinal fusion surgery in postmenopausal women with osteoporosis from a bone quality perspective. Spine (Phila Pa 1976). 2013:38(8):E487-92.

32. Tu CW, Huang KF, Hsu HT, Li HY, Yang SD, et al. Zoledronic acid infusion for lumbar interbody fusion in osteoporosis. J Surg Res. 2014;192(1):112-6. https://doi.org/10.1016/j.jss.2014.05.034.

33. Egger M, Davey Smith G, Schneider M. Minder C Bias in meta-analysis detected by a simple, graphical test. Bmj. 1997;315(7109):629-34. https://doi. org/10.1136/bmj.315.7109.629.

34. Peter CP, Cook WO, Nunamaker DM, Provost MT, Seedor JG, Rodan GA. Effect of alendronate on fracture healing and bone remodeling in dogs. J Orthop Res. 1996;14(1):74-9. https://doi.org/10.1002/jor.1100140113.

35. Zou X, Xue Q, Li H, Bünger M, Lind M, Bünger C. Effect of alendronate on bone ingrowth into porous tantalum and carbon fiber interbody devices: an experimental study on spinal fusion in pigs. Acta Orthop Scand. 2003;74(5): 596-603. https://doi.org/10.1080/00016470310018027.

36. Xue Q, Li H, Zou X, Dalstra M, Lind M, Christensen FB, et al. Alendronate treatment improves bone-pedicle screw interface fixation in posterior lateral spine fusion: an experimental study in a porcine model. International Orthopaedics. 2010;34(3):447-51. https://doi.org/10.1007/s00264-009-0759-4.

37. Huang RC, Khan SN, Sandhu HS, Metzl JA, Cammisa FP, et al. Alendronate inhibits spine fusion in a rat model. Spine. 2005;4(22):2516-22.

38. Lau CP. Huang L, Wong KC. Kumta SM Comparison of the anti-tumor effects of denosumab and zoledronic acid on the neoplastic stromal cells of giant cell tumor of bone. Connect Tissue Res. 2013;54(6):439-49. https://doi.org/1 0.3109/03008207.2013.848202.

39. Moroni A, Faldini C, Hoang-Kim A, Pegreffi F, Giannini S. Alendronate improves screw fixation in osteoporotic bone: a clinical study of pertrochanteric fractures. J Bone Joint Surg Am. 2007;89(1):96-101. https:// doi.org/10.2106/00004623-200701000-00014.

40. Samtani RG, Bernatz JT, Harrison R, Roy S. O'Brien JR The effect of alendronate on subsidence after lateral transpsoas interbody fusion: a preliminary report. Int J Spine Surg. 2019;13(3):289-95. https://doi.org/1 $0.14444 / 6039$.

\section{Publisher's Note}

Springer Nature remains neutral with regard to jurisdictional claims in published maps and institutional affiliations.

Ready to submit your research? Choose BMC and benefit from:

- fast, convenient online submission

- thorough peer review by experienced researchers in your field

- rapid publication on acceptance

- support for research data, including large and complex data types

- gold Open Access which fosters wider collaboration and increased citations

- maximum visibility for your research: over $100 \mathrm{M}$ website views per year

At BMC, research is always in progress.

Learn more biomedcentral.com/submissions 